Cahiers $d u$ MONDE RUSSE

\section{Cahiers du monde russe}

Russie - Empire russe - Union soviétique et États indépendants

49/2-3 | 2008

Sortie de guerre

\title{
Fil'tracija sovetskih repatriantov v 40-e gg. XX vv. :Celi,metody i itogi
}

Igor Govorov

\section{OpenEdition \\ Journals}

Édition électronique

URL : https://journals.openedition.org/monderusse/9134

DOI : 10.4000/monderusse. 9134

ISSN : $1777-5388$

\section{Éditeur}

Éditions de l'EHESS

\section{Édition imprimée}

Date de publication : 20 septembre 2008

Pagination : 365-382

ISBN : 978-2-7132-2196-5

ISSN : 1252-6576

Référence électronique

Igor Govorov, «Fil'tracija sovetskih repatriantov v 40-e gg. XX vv. :Celi,metody i itogi », Cahiers du monde russe [En ligne], 49/2-3 | 2008, mis en ligne le 01 janvier 2011, consulté le 24 février 2023. URL : http://journals.openedition.org/monderusse/9134; DOI : https://doi.org/10.4000/monderusse.9134 
chercher : repérer : avancer

Cet article est disponible en ligne à l'adresse :

http://www.cairn.info/article.php?ID REVUE=CMR\&ID NUMPUBLIE=CMR 49\&ID ARTICLE=CMR 4920365

Fil'tracija sovetskih repatriantov v 40-e gg. XX vv. :Celi, metody i itogi

par Igor GOVOROV

Editions de I'EHESS | Cahiers du monde russe

2008/2-3 - Vol 49

ISSN 1252-6576 | ISBN 9782713221965 | pages 365 à 382

Pour citer cet article :

-Govorov I., Fil'tracija sovetskih repatriantov v 40-e gg. XX vv. :Celi, metody i itogi, Cahiers du monde russe 2008/23, Vol 49, p. 365-382.

Distribution électronique Cairn pour les Editions de l'EHESS.

(C) Editions de l'EHESS. Tous droits réservés pour tous pays.

La reproduction ou représentation de cet article, notamment par photocopie, n'est autorisée que dans les limites des conditions générales d'utilisation du site ou, le cas échéant, des conditions générales de la licence souscrite par votre établissement. Toute autre reproduction ou représentation, en tout ou partie, sous quelque forme et de quelque manière que ce soit, est interdite sauf accord préalable et écrit de l'éditeur, en dehors des cas prévus par la législation en vigueur en France. Il est précisé que son stockage dans une base de données est également interdit. 
ИГОРЬ ВАСИЛЬЕВИЧ ГОВОРОВ

\section{ФИЛЬТРАЦИЯ СОВЕТСКИХ РЕПАТРИАНТОВ В 40-е гг. ХХ вв. \\ Цели, методы и итоги}

Советская история XX столетия породила множество дискуссионных проблем, до сих пор вызывающих научные споры и в значительной степени мифологизированных современным общественным сознанием. Значительная часть этих дискуссионных проблем относится ко времени Великой Отечественной войны. В последние двадцать лет появилось огромное количество работ как научного, так и публицистического характера, призванных пересмотреть устоявшиеся взгляды на те или иные стороны войны. При этом под знаменем борьбы со старыми «советскими» мифами о войне идёт формирование новой мифологии, имеющей весьма отдалённое отношение к реальной действительности. Одной из таких проблем, привлёкших в последние десятилетия повышенное внимание, как профессиональных историков, так и журналистов, стала деятельность органов НКВД по проверке бывших военнопленных и гражданских лиц, депортированных оккупантами во время войны за пределы страны и возвращённых в СССР после её завершения. Сегодня, в российском обществе утвердилась мысль, что в условиях бесчеловечного тоталитарного режима в Советском Союзе, все советские граждане, освобождённые из гитлеровских лагерей, независимо от того сотрудничали они с оккупантами или нет, немедленно попадали в сталинские.

Господство данной точки зрения стало следствием своеобразной ситуации, сложившейся с изучением этого вопроса в исторической науке. Советская историография в течение сорока послевоенных лет фактически замалчивала проблему организации репатриации в СССР советских граждан, 
угнанных гитлеровцами за пределы страны и тем более масштабы преследования их за коллаборационизм. В немногих имевшихся работах, косвенно затрагивавших эту тему, авторы отделывались общими фразами о том, что подавляющее большинство советских военнослужащих и гражданских лиц, попавших в руки немцев, остались верными идеям социализма и Родине. Соответственно и случаи их преследования за поддержку оккупантов были единичными и не носили массового характера ${ }^{1}$.

Западная и эмигрантская историография, наоборот исходила из тезиса, что ненависть к сталинскому режиму большинства населения привела к тому, что на оккупированных территориях гитлеровцы, которых простые люди воспринимали освободителями от большевизма, пользовались массовой поддержкой. Это, а также тоталитарная сущность советского режима, ненавидящего собственный народ, привели к тому, что практически все военнослужащие Красной армии, побывавшие в плену и окружении и мирные граждане, угнанные или добровольно выехавшие в Германию, рассматривались властями как изменники и предатели и стали жертвами жестоких репрессий ${ }^{2}$ И та и другая точка зрения носила скорее идеологический характер и не базировались на архивных источниках, которые в СССР оставались недоступными для исследователей. Западные историки строили свои выводы главным образом на таком весьма субъективном источнике, как воспоминания эмигрантов «второй волны», содержащие весьма субъективные оценки и спорные, а нередко и просто ложные сведения ${ }^{3}$.

Политические преобразования в России в 80-90-е гг. несколько изменили ситуацию. Появившиеся в стране переводные книги западных авторов, посвящённые послевоенной репатриации, и рассекречивание части архивов советского периода дали толчок $\mathrm{K}$ изучению данной проблемы и отечественными исследователями. За последние 15 лет появился целый ряд статей, монографий и диссертационных исследований, рассматривающие её различные аспекты ${ }^{4}$. (в том числе и несколько публикаций, принадлежащих

1. См. напр. В. Васильев (В.К. Соколов), «По поводу одной фальшивки», Международная жизнь, 1978, № 8., с. 124-128; С.З. Остряков, Военные чекисты, М., 1979; А. Брюханов, Вот как это было: О работе миссии по репатриации советских граждан, М., 1958.

2. См. напр. Н.Д. Толстой, Жертвы Ялты, М., 1996; Н. Бетелл, Последняя тайна, М., 1992 и др.

3. А.С. Казанцев, Третья сила, Франкфурт-на-Майне : изд-во «Посев», 1972 М.В. Кузнецов, В угоду Сталину, Лондон: изд-во СБКНОР, 1968; Ф.Я. Черон, Немецкий плен и советское освобождение, Париж: ИМКА Пресс, 1987, там же И.Я. Лугин, Полглотка свободы, и др.

4. А.А. Шевяков, «Гитлеровский геноцид и репатриация советского населения», Людские потери СССР в период Второй мировой войны, СПб., 1995, с. 178-181; В.Н. Земсков, «Репатриация советских граждан и их дальнейшая судьба», Социологические исследования, 1995, № 5-6; М.И. Семиряга, «Судьба советских военнопленных», Вопросы истории, 1995, № 4, с. 19-33; П.Е. Полян, Жертвы двух диктатур, М., 2002; А.Ф. Бичехвост, Репатриация советских и иностранных граждан, Дисс. докт. ист. наук., Саратов, 1996; В.А. Иванов, Миссия ордена, СПб., 1997; В.С. Христофоров, В.К. Виноградов и др., «Смерш»: Исторические очерки и архивные документы, М.: Издательство Главархива Москвы, 2003; А. Дюков, 
автору данной статьи $)^{5}$. Однако до сих пор в исторической науке идёт дискуссия по таким вопросам как оценки массовости коллаборационизма в годы Великой Отечественной войны, отношение Сталина и его окружения к данной проблеме, критерии зачисления граждан в категории «изменников» и «пособников» оккупантов, меры их наказания, степень распространения этой репрессивной практики на бывших военнопленных и репатриантов, специфика деятельности карательных органов СССР по выявлению лиц, сотрудничавших с оккупантами, технология и механизмы проведения т.н. «фильтрации» и то, в какой степени на неё влияли тоталитарные характеристики советского режима. Некоторые из этих вопросов поднимаются в данной статье.

Неудачный ход Великой Отечественной войны уже в 1941 г. поставил перед военно-политическим руководством страны вопрос об отношении к тысячам бойцов и командиров Красной армии, выходящим из окружения и бежавшим из плена. Свойственная сталинскому режиму шпиономания и подозрительность по отношению к своим гражданам, в какой-либо степени вышедшим из-под его контроля, казалось бы, не сулила им ничего хорошего. Тем более введённое в действие в 1927 г. Положение о воинских преступлениях предусматривало уголовную ответственность вплоть до смертной казни за «сдачу в плен, не вызывавшуюся боевой обстановкой» 6 . Параметры того, что считать условиями «не вызванными боевой обстановкой», в законодательстве не разъяснялись и их трактовка отдавалась «на откуп» следственным органам которые нередко понимали их весьма своеобразно. В 30-е гг. уже имелись прецеденты расправ с военнослужащими, побывавшими в плену. Так в ходе т.н. «Зимней войны» 1939-1940 гг. финнами было захвачено в плен более 5 тыс. бойцов и командиров Красной армии. После заключения мира в 1940 г. в Советский Союз добровольно вернулось 5359 пленных красноармейцев (отказалось репатриироваться только 99 человек). Все вернувшиеся были направлены в

«Милость к падшим: советские репрессии против нацистских пособников», Великая оболганная война-2, М.: Яуза, Эксмо, 2008, с. 98-142 и др.

5. И.В. Говоров, Репатриация на Северо-Западе РСФСР 1944-1949 г2., Дисс. канд. ист. наук., СПб., 1998; он же, «Оперативные и розыскные мероприятия в среде репатриированных советских граждан как одно из направлений деятельности органов внутренних дел и государственной безопасности в Ленинградской области (вторая половина 40 - начало 50-х гг.)», Законность, оперативно-розыскная деятельность $u$ уголовный процесс, материалы международной научно-практической конференции, 910 апреля 1998 г., ч. 1, СПб.: изд-во Санкт-Петербургской академии МВД РФ, 1998, с. 288-291; он же, «НКВД СССР и его роль в фильтрации советских граждан (19411946)», МВД России- 200 лет, материалы международной научно-практической конференции, 28-29 мая 1998 г., ч. 1, СПб., 1998. с. 206-209; он же, «Проверочнофильтрационные органы в системе НКВД 1944-1946 гг. (по материалам Ленинградской области)», Министерство внутренних дел: страниць истории (1802-2002), СПб.: фонд «Университет», 2001, с. 441-474; он же, «Проверочно-фильтрационные органы НКВД и их деятельность по выявлению гитлеровских пособников в годы Великой Отечественной войны», Государственность, социально-экономическая политика, образование и культура в годы второй мировой войны, СПб.: изд-во Государственной полярной академии, 2008, с. 65-77 и др.

6. Уголовный кодекс РСФСР с комментариями, М., 1952. с. 61. 
созданный решением Политбюро ЦК ВКП (б) от 19.04.1940 г. Южский спецлагерь НКВД для проверки их поведения в плену. Перед оперативночекистской группой лагеря была поставлена задача «выявления среди военнопленных лиц, обработанных иностранными разведками, чуждых элементов и добровольно сдавшихся финнам с последующим преданием суду». Столь широкая трактовка полномочий привела к тому, что оправданными после этой проверки (по терминологии спецслужб фильтрации) оказались менее $10 \%$ отфильтрованных - 450 человек, «попавших в плен ранеными, больными и обмороженными». Из остальных 414 человек преданы за активную предательскую деятельность суду Военного трибунала и осуждены к 19-15 годам лишения свободы или расстрелу, 4354 военнослужащих, на которых не было улик для придания суду, но имелись компрометирующие данные, были приговорены Особым совещанием при наркоме внутренних дел СССР к отправке в лагеря на срок от 5 до 8 лет ${ }^{7}$.

В условиях огромных потерь Красной Армии в ходе военных действий 1941 г. использование подобной практики было признано излишне затратным. Необходимость восполнения потерь личного состава в боевых частях и использования опыта уже обстрелянных бойцов делала применение массовых репрессий против окруженцев и военнопленных нерациональной растратой людских ресурсов. В то же время карательные органы предполагали, что немецкие спецслужбы используют выходящих из окружения для засылки своих агентов в советский тыл. Кроме того власти опасались, что бывшие окруженцы и пленные могут заразить действующие части паническими настроениями. Поэтому, было принято компромиссное решение: провести тщательную фильтрацию всех возвращающихся из плена и окружения с целью выявления среди них вражеских шпионов, диверсантов и изменников Родины. Для решения этой задачи постановлением ГКО № 1069сс от 27.12.1941 г. в рамках Управления по делам военнопленных НКВД СССР создавались спецлагеря для проверки всех «бывших военнослужащих Красной Армии находившихся в плену и окружении противника» 8 В разные периоды войны действовало от 15 до 30 спецлагерей. Спецпроверку военнослужащих в них осуществляли особые отделы лагерей, состоящие из сотрудников военной контрразведки. Однако цель их деятельности по сравнению с 1940 г. серьёзно изменилась. Теперь перед ними ставилась конкретная задача выявления среди проходящего фильтрацию спецконтингента (терминология тех лет) фашисткой агентуры, лиц добровольно сдавшихся в плен и бежавших с поля боя, а не абстрактных «чуждых элементов». За период с 1941 по 1944 г. через спецлагеря НКВД прошло 354592 военнослужащих, в том числе 50441 офицер. Была завершена проверка 302991 военнослужащего, в том числе 44774 офицера.

7. Л. Носырева, Т. Назаров, «Пойдём на Голгофу мой брат», Родина, 1995, №12, с. 104. 8. А.С. Смыкалин, Тюрьмы и колонии в Советской России, Екатеринбург, 1997, с. 276. 
Из них по завершении проверки 249416 чел. было направлено для прохождения дальнейшей службы в Красную армию (в том числе 2219 рядовых и сержантов и 16163 офицера - в штрафные роты и батальоны), 30749 (в том числе 20 офицеров) - на работу на промышленные предприятия, 5294 чел. - на службу в войска НКВД, умерло входе проверки или отправлено по болезни в госпиталь 5347 чел. Из числа проверенных арестовано органами военной контрразведки было 11566 чел. (около 3,5\%), в том числе 2083 как агенты разведки и контрразведки противника, остальные - по обвинению в дезертирстве, самовольном оставлении части в боевой обстановке, самовольном отступлении, добровольной сдаче в плен 9 .

Однако фильтрация в спецлагерях имела серьёзный недостаток длительные сроки. Обычно военнослужащий проводил в лагере несколько месяцев, подвергаясь длительным изнурительным допросам сотрудников СМЕРШ и привлекаясь к тяжёлому труду на стройках и промышленных предприятиях. Дело осложнялось многочисленными злоупотреблениями администрации лагерей, которые негативно отражались на положении спецконтингента. K числу самых распространённых злоупотреблений относились оскорбительное отношение со стороны сотрудников лагерей к проверяемым, изъятие у них и присвоение в ходе незаконных обысков ценных вещей, расхищение продовольственного и имущественного довольствия фильтруемых. Подобные факты оставались общей проблемой проверочно-фильтрационных органов и в дальнейшем. Так, в 1945 г. только в Ленинградской области к уголовной и дисциплинарной ответственности за различного рода злоупотребления был привлечен ряд сотрудников руководящего состава действовавших в области проверочнофильтрационных лагерей и Выборгского проверочно-фильтрационного пункта НКВД, включая его начальника ${ }^{10}$. Наибольший размах имело искусственное затягивание фильтрации. Руководители спецлагерей, которые несли личную ответственность за выполнение поставленных перед их учреждениями экономических планов, не были заинтересованы в потере бесплатной рабочей силы и всячески затягивали освобождение проверенных военнослужащих. Так из 8 тыс., военнослужащих, содержавшихся в Сталиногорском спецлагере НКВД в апреле 1942 - марте 193 гг., из лагеря было освобождено и отправлено в армию только тысяча человек. Остальные 7 тыс., несмотря на то, что их фильтрация была фактически закончена, продолжали содержаться в лагере, и работали в угольной промышленности ${ }^{11}$. Только за три месяца 1943 г. во 2 отдел Главного управления военной контрразведки «СМЕРШ» (который руководил

9. В.Н. Земсков, «ГУЛАГ (историко-социологический аспект)», Социологические исследования, 1991, №7, с. 4-5.

10. СРАФ УФСБ по СПб и Ло (Служба регистрации архивных фондов Управления ФСБ по Санкт-Петербургу и Ленинградской области)., Ф. ТФМ (Ф. Трофейнофильтрационных материалов), Д. 195456., Л. 35.

11. В.А. Меженько, «Военнопленные возвращались в строй», Военно-исторический журнал, 1995, № 5, с. 31-32. 
проведением фильтрации окруженцев и военнопленных) поступило более 200 жалоб от лиц, содержащихся в спецлагерях. Главным их лейтмотивом были просьбы ускорить проверку и поскорее отправить их на фронт ${ }^{12}$. В условиях постоянной потребности вооружённых сил в пополнении несущих серьёзные потери боевых частей, подобная медлительность стала неприемлемой. Поэтому явочным порядком в действующей армии на протяжении 1942 г. складывается облегчённый порядок фильтрации вернувшихся из плена и окружения военнослужащих. Все окруженцы направлялись для прохождения фильтрации на армейские сборнопропускные пункты, создаваемые в прифронтовой зоне. Спецпроверку в них проводили комиссии в составе сотрудников особого отдела и военной прокуратуры, которые ограничивались обычно 2-3 допросами, после чего проверяемый, если на него не имелось компрометирующих данных, направлялся на фронт. В спецлагеря по этой схеме отправлялись в обязательном составе только офицеры (причём чаще всего им данная мера заменялась направлением по постановлениям Военного совета фронта в штрафные батальоны сроком на три месяца) и рядовые, и сержанты, вызвавшие подозрение контрразведчиков в ходе допросов.

Однако не стоит, на наш взгляд, преувеличивать, как делают это некоторые современные российские историки «патриотического» направления, гуманизм советской власти при проведении фильтрации бывших окруженцев и военнопленных. Даже военнослужащие, благополучно прошедшие проверку, всё равно оставались в глазах сотрудников военной контрразведки подозрительной категорией лиц, ставились ими на оперативный учёт и брались в агентурную разработку. Среди арестованных особистами бывших военнопленных и окруженцев, наряду с действительными изменниками Родины и дезертирами оказалось и немало бойцов и командиров, привлечённых по сфальсифицированным обвинениям. Так, из арестованных особым отделом Краснодарского спецлагеря в период с апреля по ноябрь 1943 г. 138 проверяемых (в том числе 73 по обвинению в шпионаже) военный трибунал из-за отсутствия доказательств не признал виновным не одного ${ }^{13}$. Наиболее пристрастно при фильтрации работники СМЕРШ подходили к представителям командного состава Красной Армии, которые проверялись дольше и тщательнее и привлекались к уголовной ответственности гораздо чаще, чем рядовые военнослужащие. Подобные факты являлись логичным следствием сложившейся в 30-е гг. практики работы советских спецслужб, для которых недоверие к собственным гражданам стало одним из основных принципов их функционирования.

После начала наступательных операций советских войск, когда Красная Армия стала освобождать ранее оккупированные территории перед властями

12. «Смери»: Исторические очерки..., с. 234.

13. Там же. с. 231. 
страны встала ещё одна проблема - решение судьбы граждан в какой-либо мере сотрудничавших с гитлеровцами. Политика в отношении этой категории лиц прошла несколько этапов. Первоначально, (в декабре 1941 январе 1942 гг.) на освобождённых территориях был взят курс на массовые аресты всех лиц в какой-либо степени оказывавших содействие оккупационному режиму. В приказе НКВД СССР №001683 от 12.12.1941 г. «Об оперативно-чекистском обслуживании местностей, освобождённых от войск противника» территориальным аппаратам и особым отделам НКВД ставилась задача немедленно арестовать и предать суду «предателей, изменников и провокаторов, как состоявших на службе немецких оккупационных властей, так и способствовавших им в проведении антисоветских мероприятий и преследовании партийно-советского актива и честных советских граждан» 14 . Под столь расплывчатую формулировку могла попасть большая часть жителей освобождённых территорий, в целях выживания вынужденных во время оккупации участвовать в жизни оккупационного режима. В качестве «враждебных элементов» арестовывались зачастую не только сотрудники оккупационных учреждений и полиции, но и истопники, уборщицы, сторожа, работавшие в немецких организациях, женщины вынужденные продавать себя в публичных домах для немецких военнослужащих, и просто мужчины призывного возраста по каким-либо причинам не попавшие в армию. Вскоре карательная система стала захлёбываться от значительного числа подобных арестованных. Поэтому руководство НКВД приняло меры для исправления подобной ситуации. 18 февраля 1942 г. было издано указание НКВД СССР, чётко регламентирующие категории лиц подвергавшихся репрессиям на освобождённых территориях. Все подозреваемые в сотрудничестве с гитлеровцами подлежали обязательной фильтрации, проводимой рай- и горотделами НКВД. В ходе неё выявлялись и арестовывались сотрудники и агенты немецких спецслужб, члены сформированных захватчиками магистратов, местных самоуправлений, старосты, полицейские и другие служащие оккупационных административных органов, участники антисоветских организаций и организованных гитлеровцами воинских формирований, содержатели домов терпимости для немцев. Остальные категории лиц, сотрудничавшие с оккупационным режимом: владельцы и жильцы домов в которых размещались оккупационные учреждения, члены ВКП (б) и ВЛКСМ добровольно прошедшие регистрацию в оккупационной администрации, женщины, имевшие интимные связи с офицерами, солдатами и чиновниками германской армии, все без исключения лица, служившие в созданных немцами учреждениях и предприятиях (кроме насильно мобилизованных), все люди, добровольно оказывавшие услуги немцам, какой бы характер эти услуги не носили и члены семей лиц добровольно

14. Н.Ф. Соповая, ред., Органы государственной безопасности СССР в Великой Отечественной войне: Сборник документов, М.: изд-во «Русь», 2000. т. 2, кн. 2, с. 414. 
ушедших с немцами, а также граждане призывного возраста, уклонившиеся от мобилизации в Красную Армию, брались на агентурный учёт, а позже направлялись для дополнительной проверки в спецлагеря НКВД и арестовывались только в случае получения материалов об их активной предательской работе ${ }^{15}$.

Начавшееся в 1943 г. освобождение большей части оккупированных территорий заставили руководство страны далее дифференцировать своё отношение к различным категориям лиц, обвиняемых в содействии немцам. Было принято решение ограничить уголовное преследование наиболее «замаравшими» себя во время оккупации. В Указе Президиума Верховного Совета СССР от 19.04.1943 г. все лица, сотрудничавшие с оккупантами, были разделены на две большие категории: изменники Родины и пособники. K первым относились военнослужащие, добровольно перешедшие на сторону врага, командный состав органов полиции и военных формирований, созданных оккупантами (РОА, «Народная стража», «Народная армия», национальные легионы, казачьи формирования и т.д.), рядовые полицейские и участники данных формирований, участвовавшие в карательных операциях, убийствах мирного населения, бургомистры и другие крупные фашистские чиновники, перебежчики, сотрудники и агенты гестапо и других разведывательных и контрразведывательных органов гитлеровцев и их союзников. В число пособников зачислялись сельские старосты, рядовые полицейские и «власовцы», не замешенные в репрессиях против советских граждан, служащие немецких административных учреждений и городских управ, прочие лица, оказывавшие добровольное содействие гитлеровцам в сборе продовольствия и фуража, выполнении прочих заданий оккупационной администрации. 25.11.1943 г. появились разъяснения Пленума Верховного Суда СССР, уточнявшее те категории пособников, которые не подлежали уголовной ответственности. К ним относились пособники, саботировавшие немецкие приказы и оказывавшие содействие подпольщикам, партизанам, Красной Армии, а также мелкие служащие административных учреждений, рабочие и специалисты, занимавшиеся в условиях оккупации своей профессиональной деятельностью - врачи, агрономы, учителя, ветеринары и т.д. ${ }^{16}$

Своё практическое отражение эти указания нашли в директивах НКВДНКГБ №437/89 и 494/49, ввёдших новый порядок фильтрации в освобождённых от оккупации районах ${ }^{17}$. В соответствие с ним розыск, арест и следствие по делам агентов гитлеровских спецслужб, сотрудников карательных и полицейских органов, членов антисоветских организаций ложились на плечи органов государственной безопасности. Прочие категории пособников, изменников и гитлеровских ставленников попадали в

15. Там же, т. 3, кн. 1, с. 131-132.

16. Полян, Жертвы..., с. 75-76.

17. ОСФ ИЦ ГУВД СПб и ЛО (Отдел специальных фондов информационного центра ГУВД по Санкт-Петербургу и Ленинградской области), ф. 1, д. 96, л. 90. 
ведение сотрудников органов внутренних дел. Непосредственная работа по осуществлению фильтрации на освобождённых территориях поручалось Главному управлению по борьбе с бандитизмом НКВД СССР и его местным аппаратам - отделам по борьбе с бандитизмом (ОББ) при областных управлениях НКВД. Под их руководством местные райотделы НКВД выявляли, ставили на учёт и проводили проверку лиц, подозреваемых в содействии оккупантам. Изобличённые изменники подлежали немедленному аресту. Что касается пособников, то здесь арестовываться должны были только т.н. «активные пособники», то есть те, кто активно поддерживал гитлеровский режим. Остальных пособников предписывалось направлять для дальнейшей проверки в спецлагеря НКВД. В том случае, если и в ходе этой проверки, факты предательской деятельности с их стороны не обнаруживались, они после завершения фильтрации направлялись в армию или на работу в промышленность. Освобождались от отправки в спецлагерь только «пособники», связанные во время оккупации с Красной Армией, подпольем и партизанами. На практике нередкими оставались случаи, когда местные сотрудники НКВД и НКГБ проводили массовые аресты всех заподозренных в пособничестве гитлеровцам, не особо обращая внимание на наличие доказательств их вины. На протяжении 1943-1944 гг. центральным органам НКВД-НКГБ приходилось регулярно давать указания своим местным аппаратам об освобождении из заключения и направлении в спецлагеря тех «пособников», на которых отсутствуют материалы об их преступной деятельности.

Только в освобождённых от гитлеровских войск районах Ленинградской области в течение 1944 фильтрацию проводили 6 оперативных и 4 следственные группы ОББ Управления НКВД области общей численностью 97 человек. Ими было проверено 57 тыс. лиц, подозреваемых в сотрудничестве с оккупантами и дезертирстве. Из этого числа было арестовано 3897 человек, в том числе 799, как агенты немецких спецслужб, 3 082, как активные пособники гитлеровцев и 70 за антисоветскую деятельность $^{18}$. О результатах изменений государственной политики по отношению к пособникам можно судить по следующим цифрам. По состоянию на 18 марта 1943 г. только в 10 освобождённых от оккупации в первые месяцы 1943 г. областях юга России и Украины было арестовано советскими спецслужбами в результате фильтрации 29843 человека, в том числе 1998 в качестве агентов немецких спецслужб, 18081 в качестве немецких пособников, 5148 - дезертиров и бандитских элементов, 4618 - за антисоветскую деятельность. За период же с 1.07.1943 г. по 1.05.1945 г. на всех освобождённых территориях СССР органами НКВД было арестовано 77152 человека, в том числе дезертиров из РККА - 14 254, полицейских - 
10 048, изменников перешедших на сторону врага - 6223 , старост - 4638 человек ${ }^{19}$.

По настоящему широкие масштабы фильтрация приобрела после выдвижения Красной Армии в 1944 г. за пределы Советского Союза. Перед руководством страны встала задача возвращения в страну миллионов военнопленных и мирных жителей, угнанных на принудительные работы. Необходимость их репатриации объяснялось причинами как идеологического, так и экономического характера (прежде всего необходимостью восполнения утраченных трудовых ресурсов). В соответствии с достигнутыми на Ялтинской конференции соглашениями обязательной репатриации подлежали все граждане СССР (в границах 1939 г.), оказавшиеся в годы войны за пределами страны ${ }^{20}$. Их общее число составляло к концу войны 5917932 человека, из которых 4864457 были угнаны за границы Советского Союза, а 1153457 были отправлены на принудительные работы и в концентрационные лагеря в Прибалтику и другие западные окраины $\mathrm{CCCP}^{21}$. Все они - и военнослужащие, оказавшиеся в плену, и мирные граждане, угнанные на работу оккупантами, подлежали при возвращении в соответствии с директивами НКВД-НКГБСМЕРШ обязательной госпроверке ${ }^{22}$. Необходимость этого определялось, по мнению Кремля, следующими причинами: во-первых, наличием среди возвращающихся коллаборационистов и агентов иностранных спецслужб и, во-вторых, тем, что все «перемещённые лица» длительное время подвергались воздействию антисоветской агитации и западного образа жизни и могли встать на путь борьбы с Советской властью. Именно сомнения руководства страны в лояльности части репатриантов побудили его подвергнуть процедуре фильтрации (хотя и разной степени интенсивности) практически всех возвращающихся военнопленных и «остарбайтеров». Уже летом 1944 г. в приграничной полосе страны начинает формироваться сеть Проверочно-фильтрационных пунктов (ПФП) НКВД СССР, предназначенных для проверки возвращающихся репатриантов ${ }^{23}$. Однако окончательно построение системы проверочно-фильтрационных органов НКВД было завершено к лету 1945 г. Порядок их работы определялся постановлением ГКО №8670-сс от 22.05.1945 г., приказом НКВД-НКГБ СССР № 00706/00268 от 16.06.1945 г и рядом других приказов и директив НКВД, НКГБ и СМЕРШ ${ }^{24}$.

19. В.Ф. Некрасов, Тринадиать «железных» наркомов, М., 1995, с. 231; Дюков, «Милость к падшим...», с. 114-115.

20. А.А. Громыко, ред., Советский Союз а международных конференциях периода Великой Отечественной войны 1941-1945 г2., М.: изд-во Политической литературы, 1979 , т. 4 , с. $290,292,393-394$.

21. В.Н. Земсков, «Репатриация советских граждан и их дальнейшая судьба», Социологические исследования, 1995, № 5, С. 9.

22. СРАФ УФСБ по СПб и Ло, Ф. ТФМ, ЛФД (Личное фильтрационное дело), 2779.

23. Полян, Жертвы..., с. 192.

24. ЦГАИПД СПб (Центральный государственный архив историко-политических документов Санкт-Петербурга), ф. 25, д. 5558, л. 135. 
Сложность проведения госпроверки репатриантов состояла в необходимости осуществления её в краткие сроки (чтобы не допустить скопления в фильтрационных пунктах и лагерях значительных масс репатриируемых) и отсутствии у советских спецслужб сведений о прошлом большинства проверяемых. Для преодоления этих трудностей была сформирована многоуровневая система фильтрации, включавшая несколько этапов.

Первый этап (первичная фильтрация) проводился ещё за границей, в местах сбора репатриантов - сборных лагерях для гражданских репатриантов и сборно-пропускных пунктах для военнослужащих. Здесь действовали проверочно-фильтрационные комиссии (ПФК), состоявшие из сотрудников НКВД-НКГБ-СМЕРШ, численностью 30-50 человек. Их задачей было в кратчайшие сроки получить первичные сведения о прошлом репатриантов и их политических взглядах и в соответствии с ними распорядиться их будущей судьбой. Репатрианты регистрировались, дактилоскопировались, заполняли опросные листы. По предложению Л.П. Берии, срок проверки женщин, стариков, детей и подростков не должен был превышать 5 дней, бывших военнопленных и мужчин призывного возраста 10 дней $^{25}$. По завершении проверки в случае отсутствия компрометирующих сведений репатрианты-мужчины призывных возрастов направлялись на службу в армию или на работу в рабочие батальоны НКО СССР. В армию были призваны молодые люди, достигшие призывного возраста во время оккупации и около половины бывших военнопленных, в рабочие батальоны - остальные бывшие военнопленные и мужчины не призванные в Красную Армию до оккупации. Мужчины непризывных возрастов, непригодные к службе по состоянию здоровья и женщины отправлялись по месту жительства.

Второй этап фильтрации (вторичная) осуществлялась на границе СССР, в приграничных лагерях и ПФП (первые находились в ведении военных округов, вторые - НКВД СССР). Здесь репатриантов проверяли оперативные группы НКГБ, НКВД и СМЕРШ, передававшие свои выводы для заключения в ПФК, которую возглавлял представитель НКВД ${ }^{26}$. Для большинства репатриируемых проверка здесь занимала от одного до нескольких дней и представляла простую формальность. Более тщательному изучению подвергались те возвращающиеся, которые по каким-либо причинам не прошли первичной фильтрации или на которых были получены данные, воспринимаемые оперработниками спецслужб, как компрометирующие.

Третий, самый длительный этап фильтрации наступал после возвращения репатриантов в страну. В отношении бывших военнопленных и «остарбайтеров», проходивших службу в воинских частях и рабочих 
батальонах НКО, её проводили особые отделы данных подразделений. Проверка граждан, вернувшихся к месту жительства, осуществлялась проверочно-фильтрационными комиссиями, созданными в районах, подвергшихся фашисткой оккупации, при всех райотделах, в других регионах страны - при областных управлениях НКВД (с 1946 г. - МВД). В районные ПФК входили по 2 оперработника милиции и госбезопасности. Возглавлял комиссию начальник отдела НКВД-МВД ${ }^{27}$. Лишь после подписания им заключения ПФК о результатах фильтрации, проверка считалась завершённой, а репатриант получал постоянный паспорт. Этот этап был наиболее долговременным и продолжался от нескольких месяцев до нескольких лет.

На всех этапах фильтрации госпроверка проводилась на основе утвердившихся в системе советских спецслужб в 20-30-е гг. приёмов и принципов работы. Основная роль в её осуществлении отдавалось применению следственны и оперативны методов. К первым относились допросы проверяемых и запросы об их личности. На каждого репатриируемого заводилось личное фильтрационное дело. На всех этапах фильтрации он подвергался 5-6 допросам, собственноручно заполнял опросные листы с анкетными данными и объяснял обстоятельства попадания в плен или за границу. Во время допросов оперативники и следователи выясняли прошлое репатриантов, обстоятельства, при которых они оказались в руках фашистов, их поведение в плену и оккупации, известные им сведения о гитлеровских изменниках и пособниках и антисоветской работе среди пленных и «восточных рабочих». Протоколы допросов и опросные листы репатриантов, составленные на различных этапах проверки, сопоставлялись и анализировались с целью выявления противоречий в их ответах. Кроме того, репатриированные проверялись по оперативным учётам и розыскным спискам НКВД, НКГБ и СМЕРШ. Запросы об их личности направлялись в органы безопасности и внутренних дел, партийные инстанции во все указанные фильтрантами на допросах места прежнего жительства, работы и службы.

K оперативным методам фильтрации относилась, прежде всего, агентурная разработка проверяемых. На фильтрантов, подозреваемых в коллаборационизме или политической нелояльности заводились делаформуляры, в которых накапливались материалы оперативного характера. К ним «подводилась» агентура с целью установления фактов их враждебной деятельности. Агентурно-осведомительные сети создавались при всех органах фильтрации (сборных лагерях и пропускных пунктах, проверочнофильтрационных пунктах, лагерях и комиссиях) из числа преимущественно самих репатриантов. Так, в проверочно-фильтрационном лагере НКВД-МВД № 317 действовал 251 осведомитель, каждый из которых разрабатывал несколько фильтрантов. Так Осведомитель «Чёрный» в августе 1945 г. 
разрабатывал 3 проверяемых, содержавшихся в лагере, осведомитель «Зеркало» - 7 и т.д. ${ }^{28}$ Директивы НКВД предъявляли к будущим секретным осведомителям следующие требования: преданность идеям Советской власти, уровень образования в объёме средней школы, широкий круг связей в среде проверяемых. В большинстве своём сотрудничество репатриантов со спецслужбами объяснялось наличием на них у работников карательной системы компрометирующих материалов или стремлением получить дополнительные льготы при проверке и репатриации. От осведомителей требовалось выявлять среди репатриируемых «изменников и предателей Родины, лиц издевавшихся над советскими гражданами или пользовавшихся привилегированным положением в Германии» ${ }^{29}$. Применение агентурны методов давало значительный эффект. Так, в результате работы только одного осведомителя в проверочно-фильтрационном лагере №317 было выявлено 12 полицейских и пособников, из которых 8 арестовано $^{30}$. Также практиковалось установление лиц, подозреваемых в сотрудничестве с оккупантами, специальными агентами-опознователями, состоявшими из завербованных советскими органами госбезопасности и доказавших свою лояльность бывших власовцев, полицейских, агентов абвера и гестапо, которые разъезжали по фильтрационным лагерям и пунктам и выявляли среди репатриантов лично известных им изменников, пособников и членов антисоветских организаций. Только в течение одного месяца, мая 1945 г., агентами-опознователями Управлений контрразведки «СМЕРШ» 2 фронтов было разоблачено 159 агентов гитлеровских спецслужб и 667 лиц, служивших в РОА и германской армии ${ }^{31}$.

Всего за последние военные месяцы и в послевоенный период в СССР было репатриировано и профильтровано 5457896 граждан $^{32}$. Интенсивность фильтрации и методы её проведения зависели от личности проверяемого. Облегчённой фильтрации подлежали женщины, дети и престарелые. Наиболее долго и скрупулезно проверялись следующие категории репатриантов: бывшие командиры Красной Армии, побывавшие в плену (с точки зрения властей обязанные проявлять больший личный героизм, чем рядовые солдаты), лица освобождённые войсками западных союзников (как возможно завербованные англо-американскими спецслужбами и антисоветскими организациями), участники Сопротивления в Западной Европе (по мнению советских спецслужб многие из документов, удостоверяющих участие советских граждан в партизанских отрядах и подпольных организациях в оккупированных нацистами странах Европы и лагерях военнопленных, были сфабрикованы и использовались предателями

\footnotetext{
28. В.А. Иванов, Миссия ордена, СПб, 1997, с. 313-314

29. СРАФ УФСБ по СПб и Ло, Ф.ТФМ, ЛФД 2874, л. 2.

30. Там же, д. 195448, л. 616.

31. «Смери»: Исторические очерки..., М., 2003, с. 230.

32. Полян, Жертвы..., с. 285.
} 
для сокрытия своей службы у немцев) ${ }^{33}$ и репатрианты, занимавшие на оккупационных территориях и в лагерях военнопленных мелкие административные должности: переводчики, бригадиры, коменданты, десятники и т.д. (которые, как считали представители госбезопасности, они могли занять только при условии сотрудничества с гестапо).

По итогам фильтрации в отношении каждого проверяемого выносилось соответствующее заключение, в соответствии с которым он либо ставился на учёт в органах государственной безопасности, либо направлялся для дополнительной фильтрации в проверочно-фильтрационный лагерь (ПФЛ), либо арестовывался, либо его проверка прекращалась с направлением фильтрационного дела для постановки на оперативный учёт в областном управлении НКВД-МВД ${ }^{34}$.

Последнее означало для репатрианта благополучное завершение проверки. Его личное фильтрационное дело (ЛФД), включавшее документы первичной и вторичной фильтрации, учётные материалы репатрианта, его личные документы, изъятые при фильтрации (например, документы, выданные немецкими властями) и данные агентуры сдавалось в архив управления НКВД-МВД. Взамен временного удостоверения личности (с которым репатриант не мог выехать за пределы района) ему выдавался сначала временный, затем постоянный паспорт, оформлялась прописка. Бывшие военнопленные после завершения проверки переводились в военкоматах со специального на общий учёт, получали военные билеты и статус участника Великой Отечественной войны (время их пребывания в плену как участие в войне не учитывалось) $)^{35}$. В дальнейшем к ЛФД, сданным в архив, обращались лишь в случае поступления запросов о наличии в учётах НКВД-МВД материалов на того или иного репатрианта. Подобные запросы направлялись при решении вопросов о приёме репатрианта на работу на режимное предприятие, разрешении его переезда на жительство в приграничный или режимный район или при вступлении бывшего репатриируемого (репатриированной) в брак с сотрудником (сотрудницей) спецслужб и правоохранительных органов.

Передача репатрианта на подсобный учёт в органы госбезопасности (НКГБ-МГБ), означала, что хотя в ходе фильтрации и не были установлены факты его изменнической деятельности, он, по мнению сотрудников, проводивших проверку, является сомнительным элементом и подлежит постоянному контролю. ЛФД фильтранта передавалось в областное управление НКГБ-МГБ, где имеющиеся на него компрометирующие данные включались в Сборник компрометирующих материалов, а сам репатриант подвергался дальнейшей агентурной разработке. Основания для постановки

33. «Смери»: Исторические..., М., 2003, с. 237.

34. Подробнее о деятельности ПФЛ, ПФК и порядке оформления ЛФД репатриантов см. напр. И.В. Говоров, Репатриация на Северо-Западе РСФСР 1944-1949 г2., Дисс. канд. ист. наук., СПб., 1998.

35. СРАФ УФСБ по СПб и Ло, Ф. ТФМ, д. 195431, л. 43. 
бывших репатриантов на подсобный учёт в органах НКГБ-МГБ были самыми разными: любые сведения, в том числе не подтвердившиеся, о его сотрудничестве с оккупантами, наличие компрометирующих данных на фильтранта или его родственников в органах безопасности в довоенный период, освобождение из гитлеровской неволи войсками союзников, поддержание после возвращения связей с заграницей (переписка или просто получение письма), сокрытие при прописке, поступлении на учёбу или работу фактов нахождения в плену или за границей, упоминание имени репатриируемого (даже в положительном для него смысле) в показаниях разоблачённых гитлеровских изменников и пособников, прохождение им проверки в ПФЛ (и в тех случаях, когда она установила невиновность фильтранта), работа в период оккупации в немецких административных учреждениях (вплоть до должности уборщицы), добровольный выезд в Германию, поддержание за границей приятельских отношений с иностранцами и эмигрантами и т.д. В регионах страны, не подвергшихся оккупации, где число репатриантов было невелико, на подсобный учёт в органах госбезопасности ставились практически все вернувшиеся ${ }^{36}$. Такое пристальное внимание заканчивалось для некоторых из них арестом и судом по обвинению в шпионаже на англо-американские спецслужбы или пропаганде западного образа жизни. Из-под плотной опеки органов безопасности эта категория репатриантов была освобождена только в середине 50-х гг.

Широкий размах в ходе фильтрации приобрела отправка части репатриантов для дополнительной углублённой проверки в спецлагеря. В 1944 г. спецлагеря (с марта 1945 г. - проверочно-фильтрационные лагеря) были выведены из подчинения Управления по делам военнопленных и интернированных НКВД СССР и подчинены самостоятельному Отделу спецлагерей (позже отделу ПФЛ) НКВД СССР. Направлению в ПФЛ подлежали все репатрианты, попавшие в ходе фильтрации под подозрение, если достаточных доказательств для привлечения их к уголовной ответственности не было. Спецконтингент, содержащийся в ПФЛ, делился на две категории. К первой относились бывшие военнослужащие, побывавшие в плену, ко второй рядовые полицейские, власовцы, старосты, прочие мелкие коллаборационисты и антисоветские элементы ${ }^{37}$. Бывшие военнопленные оказывались в ПФЛ в тех случаях, когда они, по каким то причинам не прошли первичной фильтрации или документы о её прохождении были утрачены или имелись данные о каком-либо их сотрудничестве с гитлеровцами. Это сотрудничество виделось ряду работников спецслужб, проводивших проверку, в участии военнопленных в принудительных инженерно-технических работах, ремонте вражеской техники, благоустройстве квартир гитлеровцев и, даже, в вызовах на допросы в

36. Смыкалин, Тюрьмы и колонии..., с. 281-282.

37. СРАФ УФСБ по СПб и Ло, ф. ТФМ, д. 195428, л. 237. 
полицию и жандармерию. Часть бывших военнопленных оказалось в ПФЛ только потому, что работники НКВД и СМЕРШ, проводящие фильтрацию, желали перестраховаться и не хотели брать на себя ответственность за вынесение заключения о фильтрации. Они предпочитали в массовом порядке отправлять репатриантов в ПФЛ со стандартной формулировкой, ничем не подтверждённой в материалах дела - «дезертировал, добровольно перешёл на сторону врага, работал на немцев» ${ }^{38}$. Подобная практика приобрела такой размах, что пришлось издать несколько приказов, запрещавших направление репатриантов в ПФЛ без чётких данных об их сотрудничестве с гитлеровцами. Также обязательной отправке в ПФЛ подлежали репатрианты, арестованные по обвинению в измене, а затем освобождённые из-за отсутствия доказательств их вины.

По состоянию на конец 1945 г. в ПФЛ проходило проверку 600 тыс. человек ${ }^{39}$. Они содержались на положении заключённых, снабжались по нормам ГУЛАГа и привлекались во время пребывания в лагере к труду на стройках и промышленных предприятиях. Одновременно фильтранты подвергались тщательной и всесторонней проверке, проводимой оперативночекисткими отделами лагерей и приданными им сотрудниками территориальных органов НКВД-НКГБ и военной контрразведки. Большинство ПФЛ просуществовало до 1946 г. Уже весной этого года количество спецконтингента в ПФЛ сократилось до 228 тыс. человек, к началу 1948 г. - до 2993 человек, в том числе 2386 служивших в немецкой армии. Последний ПФЛ был ликвидирован в 1953 г. ${ }^{40}$

Достаточно широко распространено мнение, что все попавшие в ПФЛ были обречены на осуждение и отправку в ГУЛАГ. Проведённые автором, исследования судеб спецконтингента, прошедшего проверочнофильтрационных лагеря, действовавшие в Ленинградской области в 1945 1946 гг., позволяют опровергнуть эту точку зрения. Большинство фильтрантов как 1, так и 2 категории, проходивших в них проверку, (около $70 \%$ ) после её завершения были освобождены и направлены в постоянные кадры промышленности (то есть с запрещением под угрозой уголовной ответственности менять место работы), около 5\% арестовано и $25 \%$ выслано на спецпоселение ${ }^{41}$. Ссылке на спецпоселение на 5 лет подлежали согласно Постановлению ГКО от 18.08.1945 г. власовцы, полицейские, лица, служившие в немецкой армии, которые не участвовали в боевых действиях против Красной Армии и партизанских отрядов, карательных акциях против мирного населения. Освобождались от отправки на спецпоселение лица данной категории, добровольно перешедшие на сторону Красной Армии и

38. Там же д. 195445 , л. 480-481.

39. «Судьба военнопленных и депортированных граждан СССР. Материалы комиссии по реабилитации жертв политических репрессий», Новая и новейшая история, 1996, № 2, c. 100 .

40. Там же, с. 101.

41. СРАФ УФСБ по СПб и Ло, Ф. ТФМ, д. 195428, 195443, 195444. 
партизанских формирований и участвовавшие в боях на их стороне, инвалиды и нетрудоспособные, полицейские отказавшиеся уйти с немецкими войсками ${ }^{42}$. Весной 1946 г. (по постановлению Совета Министров СССР № 843-342сс от 13.04.1946 г.) со спецпоселения и из ПФЛ были освобождены и возвращены в Прибалтику литовцы, латыши и эстонцы, мобилизованные в немецкую армию ${ }^{43}$. В 1950 г. на спецпоселении (то есть проживании в определённом месте в отдалённых районах страны под надзором МВД) находилось 177753 тыс., относящихся к категории «власовцев». К концу 1952 г. большинство из них - 95553 человека были сняты с учёта спецпоселений. Остальные либо были арестованы, либо как представители «репрессированных» национальностей переведены на «вечное» спецпоселение, либо были временно оставлены на спецпоселении до завершения строительства объектов, на которых они были заняты ${ }^{44}$.

Аресту в ходе фильтрации подлежали агенты иностранных спецслужб, активные коллаборационисты и репатрианты, ведущие систематическую антисоветскую агитацию (то есть критикующие положение в СССР). В июле 1945 г. Верховным советом СССР была объявлена амнистия, по которой были освобождены от уголовной ответственности военнослужащие, добровольно сдавшиеся в плен (п.4 ст.193 УК РСФСР). Практически всем репатриантам, арестованным в ходе фильтрации, предъявлялись обвинения в контрреволюционных преступлениях (различные пункты ст. 58 УК РСФСР). По данным статистики всего в ходе фильтрации было репрессировано (включая отправку на спецпоселение) около $14 \%$ репатриантов ${ }^{45}$. По оценкам современных исследователей, анализировавших уголовные дела на осуждённых власовцев и других изменников, следствие по ним велось достаточно квалифицированно и в соответствии с основными требованиями уголовно-процессуального законодательства ${ }^{46}$. Тем не менее, часть уголовных дел против репатриантов было прямо сфальсифицирована. Жертвами предвзятости со стороны работников карательной системы в основном становились граждане, работавшие у немцев в должностях бригадиров, переводчиков, десятников, управдомов, поваров, председателей уличных комитетов и т.д. Воспоминания репатриируемых свидетельствуют о случаях фабрикации доказательств, применения мер физического принуждения к арестованным, использовании лжесвидетелей при искусственном создании дел о «измене Родине». Однако, на наш взгляд, надо признать, что данные факты не носили характер санкционированных сверху репрессий, направленных на уничтожение всех репатриантов. Руководство страны требовало от спецслужб не поголовного ареста и осуждения, репатриируемых по «липовым» обвинениям, а выявления среди них

42. «Судьба военнопленных...», с. 107.

43. Дюков, «Милость к падшим...», с. 134-135.

44. В.Б. Жиромская, ред., Население России в ХХ веке: Исторические очерки, т. 2, М.: 2001, c. 171 .

45. Там же, с. 154.

46. А. Бахвалов, Генерал Власов: Предатель или герой, СПб: 1994, с. 96. 
действительных коллаборационистов и противников Советской власти. Факты фабрикации дел против репатриантов были следствием скорее не установок сверху, а сложившейся в органах госбезопасности практики улучшения показателей своей работы за счёт сфальсифицированных уголовных дел.

Аресты изменников и пособников продолжались и в последующие годы. Так в 1946 г. за сотрудничество с оккупантами было арестовано 32859 человек, в 1948 - 23 912, в 1949 - 19567 , в 1950 - 16 634, в 1951 - 14 447, а в 1952 - 3630 человек. ${ }^{47}$ Притом, в условиях начавшейся «Холодной войны», отношение к пособникам заметно ужесточилось. Если в 1945-1946 гг. они осуждались на 5-10 лет лишения свободы, то к началу 50-х гг. меры наказания для них были ужесточены до 25 лет лишения свободы. Аресты в этот период затронули и пособников ранее благополучно прошедших фильтрацию. В 1952 г. заместителем главного военного прокурора СССР Е. Варским было дано указание прокурорам, поддерживающим обвинение по делам о пособничестве в Военных трибуналах, не ставить вопрос о смягчении наказания, даже если пособник частично искупил вину в боях с немцами (в составе партизанских отрядов и частей Красной Армии) ${ }^{48}$.

Однако и эти репрессии затронули лишь небольшую часть репатриированных. Основное число репатриантов в 40-50-е гг. страдало не от уголовных репрессий, а от негласного ограничения своих прав. Формально являясь полноправными советскими гражданами, на практике они превратились в граждан «второго сорта», перед которыми были закрыты возможности получения высшего образования и престижной должности, осуществления партийной и военной карьеры, свободного выбора места жительства и работы и т.д.

Таким образом, в ходе Великой Отечественной войны в СССР органами НКВД-НКГБ-СМЕРШ была создана разветвлённая, многоуровневая система проверочно-фильтрационных органов. В её функции входила проверка военнослужащих Красной Армии, побывавших в плену и окружении, лиц подозреваемых в коллаборационизме и советских граждан, репатриированных из-за границы. В ходе масштабных фильтрационных мероприятий было выявлено и подверглось различным наказаниям или взято под негласный контроль большинство лиц, так или иначе сотрудничавших с оккупантами. Однако в силу тоталитарного характера советского режима эти мероприятия приняли ярко выраженную репрессивную направленность и привели к ограничению в правах и свободах миллионов граждан страны, даже в тяжелейших условиях нацисткой неволи не вставших на путь предательства.

\section{Университет МВД России}

igogovoro@yandex.ru

47. Дюков, «Милость к падшим...», с. 129

48. Г.М. Иванова, ГУЛАГ в системе тоталитарного государства, М.: 1997, с. 56. 